\title{
Impact of metabolism and production diseases on reproductive function in dairy cows
}

\author{
Heinrich Bollwein ${ }^{1}$, Chiho Kawashima ${ }^{2}$, Takashi Shimizu ${ }^{3}$, Akio Miyamoto ${ }^{3}$ \\ and Martin Kaske ${ }^{1}$ \\ ${ }^{1}$ Clinic of Reproductive Medicine, Vetsuisse-Faculty, University of Zurich, Switzerland; ${ }^{2}$ Field Center \\ of Animal Science and Agriculture, Obihiro University of Agriculture and Veterinary Medicine, \\ Hokkaido, Japan; ${ }^{3}$ Graduate School of Animal and Food Hygiene, Obihiro University of Agriculture \\ and Veterinary Medicine, Hokkaido, Japan
}

\begin{abstract}
Summary
The increase of milk yield in dairy cows during the last decades has been accompanied by a reduction in fertility. This decline in reproductive performance is most likely caused by the pronounced negative energy balance typically observed in high yielding dairy cows and in cows suffering from production diseases. Often, both phenomena occur coincidentally. Cows with a profound negative energy balance and production diseases show hormonal alterations compared to healthy cows which impair follicular development and oestrous behaviour, delayed resumption of ovarian cyclicity, increased risk of a persistent corpus luteum and decreased peripheral progesterone concentrations, with negative impacts on oocyte quality and embryonic development. However, until now it has not been proven that inflammatory diseases induce embryonic mortality. There is, on the other hand, strong evidence that a negative energy balance causes disturbances in uterine involution by an impairment of immune defense mechanisms. The underlying pathophysiological mechanisms are not yet completely clarified. It has been demonstrated, however, that an early ovulation after parturition delays the process of uterine involution. Taken together, both metabolic disorders as well as inflammatory processes have diverse negative effects on reproductive function and are some of the reasons for the decline of fertility in high yielding dairy cows.
\end{abstract}

\section{Introduction}

The critical challenge in intensive dairy production systems is to achieve a high milk yield, while simultaneously maintaining an appropriate level of animal health. Clearly, genetic selection for greater milk production is a risk factor for a variety of production diseases. Longevity of highproducing dairy cows is, however, economically feasible as it maximizes the life efficiency of dairy cows (expressed as kg milk per day of lifetime). In addition, longevity addresses society's concerns regarding animal welfare. Fertility represents a prerequisite for longevity. Thus, the interactions between milk yield, health and fertility have been a focus of researchers worldwide. 
Fertility, defined as conception within a defined period of time after the previous calving leading to the delivery of a fully developed calf, is affected both by milk yield in early lactation and the health status of the cow - importantly, these factors interact with each other. The transition from late pregnancy to early lactation represents the period of highest impact on subsequent fertility for several reasons.

First, independently of their specific etiology, any type of dystocia (e.g., twins, posterior presentation, oversized calf) increases the risk for retained placenta, puerperal metritis and subsequent chronic endometritis, lowering the probability for a successful subsequent insemination.

Second, negative energy balance (NEB) is common in high-producing dairy cows as the initial milk production is too high relative to feed intake and increases in feed intake lag behind those of milk production (Ingvartsen \& Andersen 2000, Bobe et al. 2004). In this situation, precursors for hepatic gluconeogenesis, protein and minerals are lacking (Bobe et al. 2004, Duffield et al. 2008). NEB tends to be more pronounced in high yielding dairy cows than in lower yielding animals. Accordingly, peripheral and abdominal fat, as well as muscular tissue, are mobilized. The elevated levels of non-esterified fatty acids (NEFA) are well-known triggers of insulin resistance, which is characterized by reduced biological effects of insulin due to a decreased peripheral response (Hayirli et al. 2002, Kaske et al. 2004, de Koster \& Opsomer 2013). Further triggers of insulin resistance, such as catecholamines and inflammation mediators, provoke elevated NEFA concentrations. Under these conditions, however, the onset of ovarian activity is delayed. Moreover, even the metabolic status throughout the dry period affects ovarian activity post partum (Castro et al. 2012).

Third, cows suffer from production diseases such as hypocalcemia, retained placenta, endometritis, ketosis, mastitis, abomasal displacement and claw diseases, predominantly throughout the first weeks of lactation (Fleischer et al. 2001). This is due to immunosuppression which has been demonstrated for cows around calving (Ster et al. 2012). Furthermore, factors related to NEB, such as elevated concentrations of ketone bodies and NEFA, increase the risk of production diseases (Mulligan \& Doherty 2008, Roberts et al. 2012). As all production diseases enhance the risk of reduced feed intake, a vicious cycle may be implemented which further increases the risk of infertility particularly due to cystic ovarian follicles. Thus, not surprisingly, the risk for pregnancy loss was found to be markedly higher in cows experiencing a combination of poor body condition and mastitis at 70 days post partum compared to cows which had solely either mastitis or a lower body condition score (Hernandez et al. 2012).

In general, however, it has to be emphasized that cows are able to cope with NEB (Bauman \& Currie 1980, Herdt 2000). Thus, there is no inevitable relationship between milk yield, the incidence of metabolic disturbances and infertility per se. Instead, there is general consensus that metabolic disturbances develop as a result of the insufficient adaptation capacity of the affected cows, which underscores the impact of individual disposition (Bauman \& Currie 1980, Herdt 2000, Ingvartsen \& Andersen 2000). The lack of clear evidence for a direct relationship between milk yield and production diseases may be due to the importance of the herd management for the health status of the herd. At present, the incidence of production diseases seems to be influenced more by the expertise of the farm manager than by the level of milk yield (Fig. 1).

\section{Impact on ovarian follicles after parturition}

In most dairy cows, several follicles appear within the first week and a dominant follicle develops in the second week after parturition (Savio et al. 1990a, Savio et al. 1990b). However, only about $50 \%$ of all cows ovulate during the first three weeks after parturition (Lucy et al. 1992, 


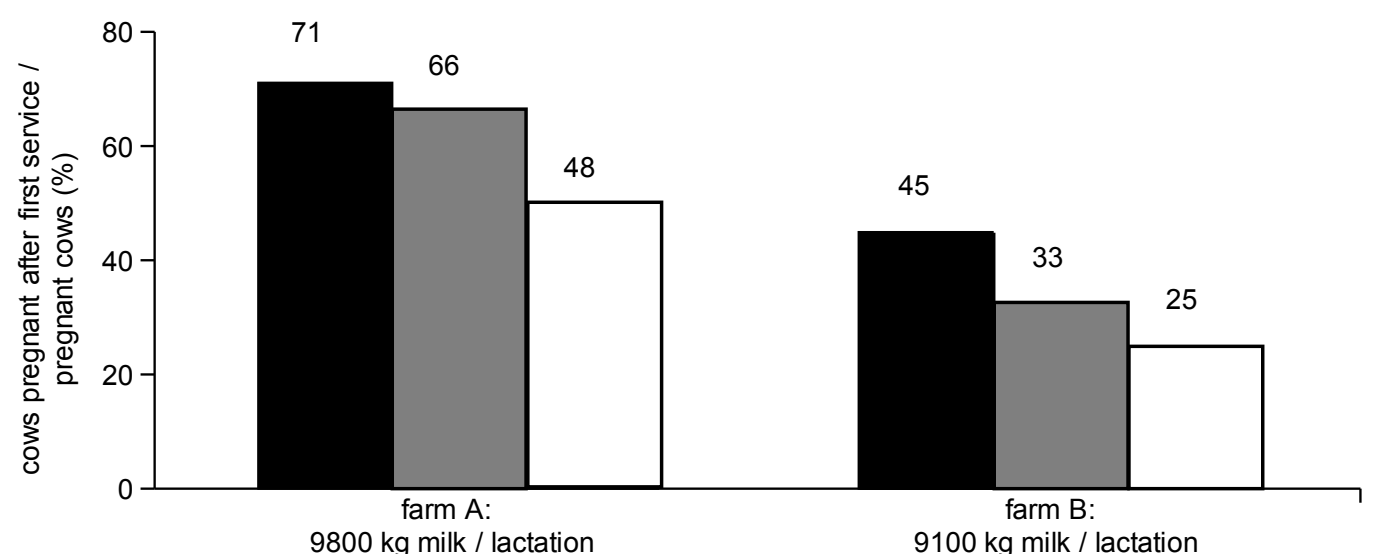

Fig. 1. Fertility (percentage of cows pregnant after first service in relation to all pregnant cows) of dairy cows with different milk yield per lactation (black bars: $\leq 6000 \mathrm{~kg}$; gray bars: $6001-8000 \mathrm{~kg}$; white bars: 8001-10000 kg milk / lactation) on two farms with differences in herd milk yield per lactation (farm A: $9800 \mathrm{~kg}$; farm B: $9100 \mathrm{~kg}$ ). The data show that the effect of farm management on fertility was higher than the effect of milk yield (A Wangler, unpublished observations 2006).

Darwash et al. 1997b, Lamming \& Darwash 1998). In the remaining cows, the dominant follicle during the first postpartal follicular wave becomes either atretic or cystic, and the first ovulation occurs at about the fourth follicular wave after parturition (Kawashima et al. 2012). The duration between parturition and resumption of luteal activity is related to the extent of the NEB in the first weeks of lactation. Cows with a more pronounced NEB between the first and second week postpartum ovulate later compared to cows with a moderate NEB (Staples et al. 1990).

The metabolic alterations during the transition period affect the follicular activity after parturition for several reasons. First, decrease of dry matter intake towards the end of pregnancy and the homeorrhetic changes typical during the onset of lactation (Bertics et al. 1992, VazquezAnon et al. 1994) provoke an uncoupling of the somatotropic axis characterized by low IGF-I concentrations irrespective of increased growth hormone $(\mathrm{GH})$ secretion from the pituitary gland (Kunz et al. 1985). IGF-I is well-known as a sensitive signal between metabolism, NEB and reproduction (Konigsson et al. 2008).

However, IGF-I levels do not only change within cows but also differ between animals. IGF-I concentration in blood plasma is a heritable trait, with heritability estimates ranging from 0.23 to 0.52 (Davis \& Simmen 1997, Grochowska et al. 2001, Davis \& Simmen 2006, Swali $\&$ Wathes 2006). Cows developing production diseases post partum exhibit significantly lower IGF-I concentrations several weeks before calving compared to cows remaining healthy in the transition period (Piechotta et al. 2012).

GH stimulates lipolysis in adipose tissues (Dominici \& Turyn 2002, Andersen et al. 2004) to provide the cows with sufficient energy (Herdt 1988). If lipolysis is too high, NEFA levels will increase. In the face of postpartal NEB, the liver becomes GH resistant (Thissen et al. 1994, Lang \& Frost 2002), i.e., the $\mathrm{GH}$ receptors in the liver are down-regulated and the stimulating effect of $\mathrm{GH}$ on the synthesis of IGF-I is reduced. Therefore, plasma concentrations of IGF-I decrease from about 3 weeks prepartum to 1 week postpartum despite an increase in GH (Andersen et al. 2004, Meikle et al. 2004, Taylor et al. 2004). In addition, plasma concentrations of insulin decrease before and after parturition, except for an acute surge at parturition (Holtenius et 
al. 2003, Taylor et al. 2004). Insulin plays a central role in the homeostatic control of energy metabolism and its concentration is positively correlated with energy intake (Chilliard et al. 1998). This endocrine constellation around parturition affects ovarian function. Bovine follicles possess IGF-I- and insulin receptor mRNA (Spicer et al. 1994, Sudo et al. 2007, Shimizu et al. 2008). Liver-derived IGF-I is a factor in regulating the final maturation of the dominant follicle during the first postpartal follicular wave (Beam and Butler 1998), and regardless of parity, circulating IGF-I in ovulatory cows at the first follicular wave postpartum is higher than that in anovulatory cows (Beam \& Butler 1998, Kawashima et al. 2007a, Kawashima et al. 2007b) (Fig. 2). Hence IGF-I, as well as insulin, directly stimulates both the proliferation of granulosa cells and steroidogenesis. Thus, low IGF-I- and insulin concentrations being typical for the first weeks of lactation reduce the probability of ovulation (Armstrong et al. 2001, Armstrong et al. 2003, Gong 2002).
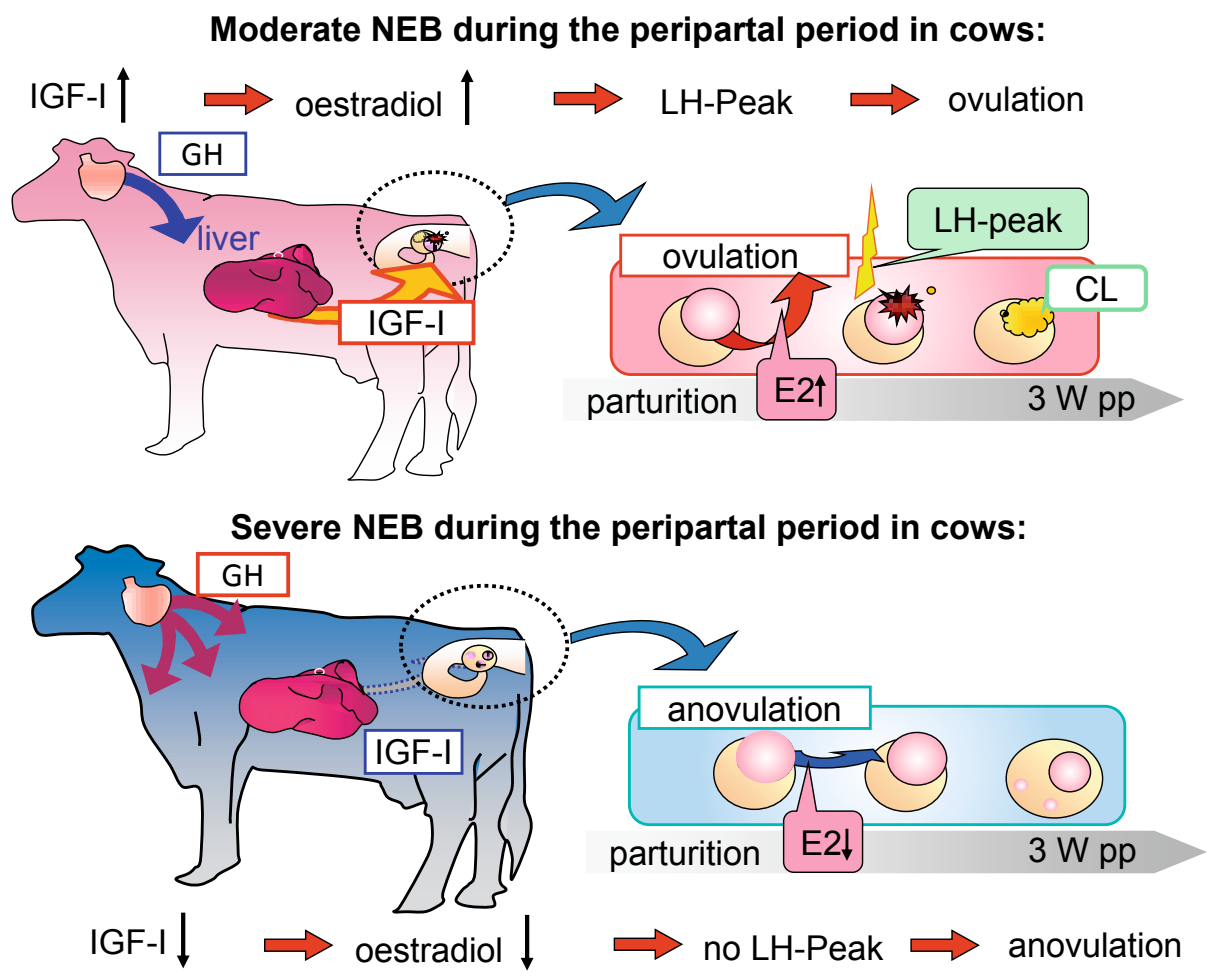

Fig. 2. Schematic presentation of the effect of the degree of peripartal negative energy balance on development of the dominant follicle within the first three weeks after parturition in dairy cows (mod. from Kawashima et al. 2012).

Low plasma glucose concentrations are frequently found in recently calved cows due to the high glucose demand of the mammary gland to support milk synthesis (Harrison et al. 1990, Andersen et al. 2004, Schlamberger et al. 2010) while elevated plasma NEFA concentrations reflect peripheral lipolysis. The serum concentrations of these metabolites are also reflected in the follicular fluid of the dominant follicle. In vitro studies showed that NEFAs have negative effects on the quality of oocytes, cumulus cells and resultant blastocysts (Leroy et al. 2006, Van Hoeck et al. 2013). In fact, higher plasma NEFA concentrations during the peripartum period are associated with delayed ovulation in postpartum dairy cows (Giuliodori et al. 2011). Therefore, 
postpartal changes of serum concentrations of these metabolites alter the pattern of ovarian follicle growth and development, resulting in reduced reproductive performance in dairy cows.

High yielding dairy cows experiencing pronounced NEB during the transition period do not only exhibit a prolonged period of anoestrus. Remarkably, even when these cows initiate oestrous cycles following a period of anovulation or anoestrus, conception rate is compromised (Gumen et al. 2003, Rhodes et al. 2003, Cerri et al. 2004, Galvao et al. 2004). Lack of progesterone (P4) and lower concentrations of oestradiol (E2) during prooestrus in the oestrous cycle preceeding AI might result in shortened oestrous cycles due to premature luteal regression (Mann \& Lamming 2000, Shaham-Albalancy et al. 2001). According to the hypothesis of Britt (1991) damage to primary follicles induced by a NEB during the first weeks after parturition may cause disturbances of the ovulatory follicles developing around 60 to 80 days later. Such follicles may contain oocytes of lower quality and a reduced capacity to synthesize steroid hormones. These disturbances could be another reason for lower conception rates in cows exhibiting a NEB during the transition period.

However, follicular activity in postpartum dairy cows is not only affected by metabolites and hormones, but also by inflammatory mediators. Metritis and mastitis are considered to be the most common infectious diseases during the postpartum period. Within three weeks after parturition, up to $40 \%$ of cows develop metritis (Sheldon et al. 2009) and mastitis is found in approximately $20-50 \%$ of all dairy cows (Wilson et al. 1997, Pitkala et al. 2004). Infectious diseases often perturb normal ovarian cyclic activity, resulting in abnormal folliculogenesis, development of cystic ovarian follicles or prolonged anoestrus (Opsomer et al. 2000, Mateus et al. 2002). In fact, in cows with metritis the first postpartum dominant follicle had reduced growth and peripheral plasma E2 were found to be lower (Williams et al. 2007).

Escherichia coli (E. coli) is an important infectious agent causing metritis and mastitis. Much of the tissue pathology is associated with endotoxins from gram-negative bacteria, the lipopolysaccharides (LPS). LPS has been detected in plasma, uterine fluid (Mateus et al. 2003), and follicular fluid (Herath et al. 2007) of cows with metritis and in the plasma and milk of cows with E. coli mastitis (Hakogi et al. 1989). It has been reported that LPS act at either hypothalamus or pituitary gland to suppress gonadotrophin release and perturb follicle growth and function (Suzuki et al. 2001).

Moreover, LPS are assumed to have a direct effect on the ovary, including follicular components such as the theca and granulosa cells and the oocyte. In bovine follicles, granulosa cells express toll-like receptors 4 (TLR4) which are activated through LPS, indicating that follicular cells are capable of responding to LPS. In vitro studies have shown that LPS suppressed E2 production by down-regulation of transcripts for P450 aromatase in granulosa cells from both large and small follicles (Herath et al. 2007, Shimizu et al. 2012).

Recently it has been shown, that LPS also reduce the primordial ovarian follicle pool in the bovine ovarian cortex ex vivo and in the murine ovary in vivo (Bromfield \& Sheldon 2013). These findings may provide further explanation as to why cows affected by infectious production diseases during the first weeks after parturition exhibit lower fertility.

\section{Impact on ovarian follicles of offspring}

Strikingly, metabolic and inflammatory triggers do not only affect ovarian follicles during the puerperal period in the cow, but also ovarian activity in the developing foetus (Evans et al. 2012, Mossa et al. 2013). Mossa et al. (2012) studied the effect of restrictive feeding of pregnant cows $(60 \%$ of their maintenance energy requirements shortly before conception until the end 
of the third month of pregnancy). Although birth weight of the offspring was unaltered, antral follicle number in calves born from restrictively fed dams were $60 \%$ lower compared with calves born from controls. Cows with a higher number of antral follicles show higher pregnancy rates, a shorter calving to conception interval and fewer services during the breeding season compared to cows with a low number of antral follicles (Mossa et al. 2012). Thus, the results of this experiment provide evidence that maternal NEB during pregnancy may have an important trans-generational impact on the size of the ovarian reserve and thereby the fertility of the offspring. The same research group examined the effects of mastitis occurring during pregnancy on ovarian development of their offspring and observed that dairy cows with a high number of somatic cells in the milk (>200 000 cells $/ \mathrm{ml}$ ) several (4 or 5) times during pregnancy gave birth to female calves with relatively low circulating concentrations of anti-Müllerian hormone (AMH) as adults. Anti-Müllerian hormone is a glycoprotein produced exclusively by granulosa cells of healthy growing follicles (La Marca \& Volpe 2006) and circulating AMH concentrations are highly correlated with the number of antral follicles and the size of the ovarian reserve in cattle and other species (Ireland et al. 2011). Therefore, these results indicate that chronic infections during pregnancy of dairy cows diminish the size of the ovarian reserve, with potentially negative effects on the future reproductive performance in their offspring.

\section{Impact on oestrus behaviour}

In the last five decades the percentage of cows that have been observed in oestrus and stand to be mounted has declined from $80 \%$ to $50 \%$. Moreover, the duration of oestrus became shorter from $15 \mathrm{~h}$ to $5 \mathrm{~h}$ over the past 50 years (Dobson et al. 2008) due to a negative relationship between milk yield and duration of oestrus (Lopez et al. 2004). A possible reason are reduced E2 concentrations as a result of a higher metabolism of this hormone (Wiltbank et al. 2006). Lactating cows have a higher liver blood flow and increased metabolic clearance of E2 compared to non-lactating cows (Sangsritavong et al. 2002). Another reason for lower E2 levels may be lower IGF-I levels in high yielding dairy cows (Lucy 2000).

Production diseases also have a negative effect on oestrus behaviour. For example, lame cows may be unable to mount herdmates. However, other production diseases such as mastitis induce acute as well as chronic stressors which affect the hypothalamus-pituitary-adrenal gland axis and the hypothalamus-pituitary-ovarian axis (Dobson \& Smith 2000). Hence, GnRH and LH pulse frequency are reduced leading to short-term decreases in follicular E2 production, as well as delaying and reducing of the magnitude of the LH surge (Dobson et al. 2007).

\section{Impact on progesterone}

Progesterone has a key role in reproductive performance, especially during pregnancy. For example, in the oestrous cycle preceeding insemination, low systemic P4 concentrations have been shown to be detrimental to conception rate (Inskeep 2004, Lonergan 2011). Although not all mechanisms responsible for this phenomenon are fully understood, it is well known that the pulsatile release of GnRH and thus of LH is suppressed by P4 (Kinder et al. 1996). The frequency of $\mathrm{LH}$ pulses has a significant influence on the development and ovulation of the dominant follicle (Fig. 3). If P4 concentrations are high, LH pulse frequency is low and the dominant follicle undergoes atresia during dioestrus. In contrast, if P4 values are low during dioestrus, LH pulse frequency is higher. As during dioestrus this increase in LH never reaches follicular-phase-type frequencies that are necessary for the final maturation of the preovulatory follicle and ovulation, 


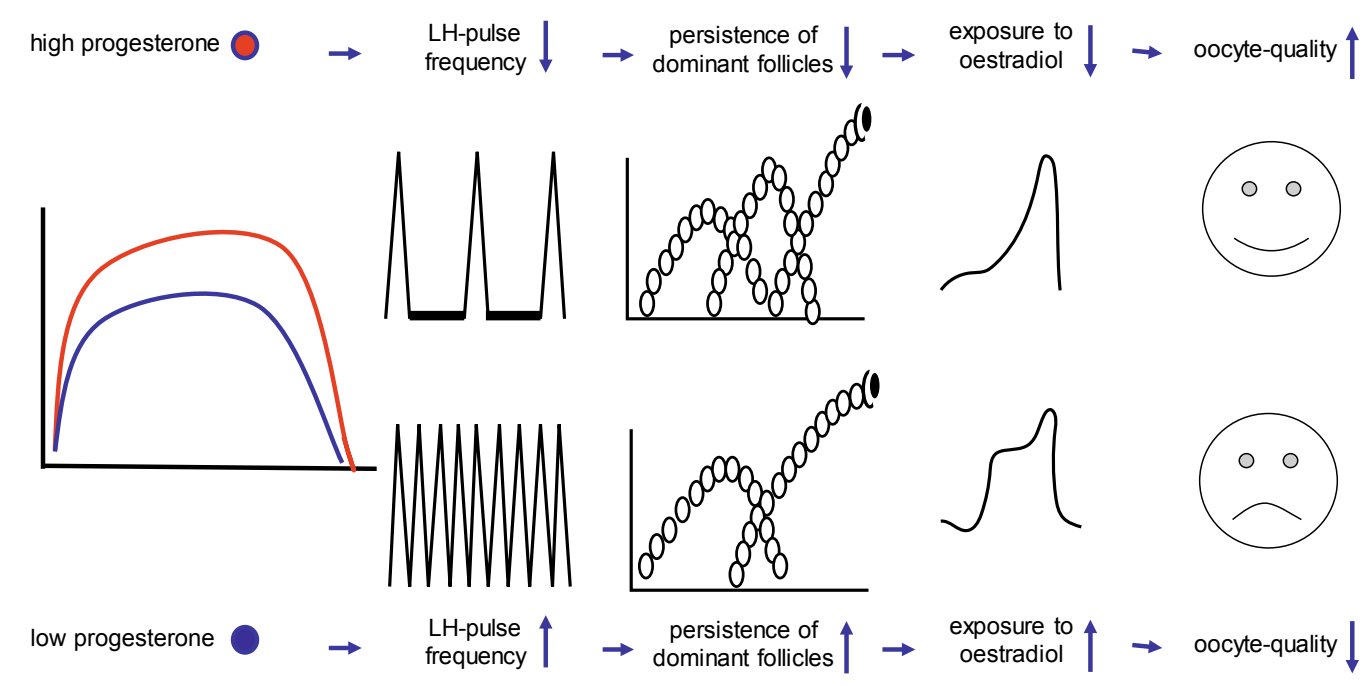

Fig. 3. Schematic presentation of the effect of the concentration of progesterone levels on follicular waves during dioestrus and on oocyte quality of the ovulatory follicle (mod. from Inskeep 2004).

the dominant follicles show a longer persistence. Cows with follicles persisting more than four days have been shown to have lower pregnancy rates (Mihm et al. 1994, Mihm et al. 1999).

After insemination, the postovulatory P4 rise between days 4 and 7 is important (Stronge et al. 2005, Diskin \& Morris 2008). P4 alters secretion of histotrophs by the endometrium enhancing the growth and development of the embryo. Thus, cows with a steep increase in P4 concentrations between days 4 and 7 after insemination have a greater chance of maintaining a pregnancy than animals with a delayed rise (Diskin \& Morris 2008). Accordingly, a fivefold increase in systemic P4 concentrations early post conception was associated with an increase in the size of the embryo on days 13 and 16 of pregnancy (Carter et al. 2008).

One reason for low peripheral P4 concentration is a reduced secretion of the CL. The synthesis of P4 by the CL can be affected by several mechanisms, especially by disturbances in the development of the ovulatory follicles during the previous oestrous cycle (Robinson et al. 2006). A smaller ovulatory follicle develops a smaller CL which synthetizes lower amounts of P4 (Vasconcelos et al. 2001). Another reason is higher metabolism of P4. Like E2, P4 is metabolized in the liver. Therefore, the increased feed intake and hepatic blood flow of high yielding dairy cows results in an elevated clearance of P4 and thereby lower peripheral P4 concentrations. Thus, negative correlations exist between P4 concentrations in the blood during the luteal phase and milk yield, as well as dry matter intake (Wiltbank et al. 2006).

P4 concentrations in dairy cows can also be negatively affected by inflammatory diseases. For example, cows with severe bacterial uterine contamination have smaller CLs and lower P4 concentrations than healthy cows (Williams et al. 2007, Struve et al. 2013). The pathogenesis of luteal impairment caused by metritis is unclear. Metritis is accompanied by increased PGF $_{2 \alpha}$ plasma concentrations (Thompson et al. 1987, Del Vecchio et al. 1994, Mateus et al. 2003), which possibly disturb luteal development. Other inflammatory mediators, such as tumor necrosis factor- $\alpha$, which may be released during metritis, are cytotoxic to bovine luteal cells (Petroff et al. 2001). Furthermore, as stated above, endotoxins inhibit the responsiveness of the pituitary gland to GnRH (Williams et al. 2001), which in turn could affect luteal development. 
In addition, persistent CLs are frequently found in cows suffering from metritis (Opsomer et al. 2000, Mateus et al. 2002, Taylor et al. 2003). The persistent CL has been determined as one of the most frequent abnormal ovarian activities in dairy cows, with a prevalence of 11 to $35 \%$ (Fonseca et al. 1983, Lamming \& Darwash 1998, Opsomer et al. 2000, Mateus et al. 2002, Zulu et al. 2002, Gumen et al. 2005, Pollott \& Coffey 2008). Although the pathogenesis of a persistent $\mathrm{CL}$ is not clearly understood, some studies have provided evidence that the luteotropic prostaglandin, PGE, which is elevated in cows showing uterine inflammation, might be involved (Henderson et al. 1977, Gimenez \& Henricks 1983, Reynolds et al. 1983, Akinlosotu et al. 1986, Thibodeaux et al. 1992). The impact of persistent CLs on bovine fertility is largely unknown. While some authors (Taylor et al. 2003) found no difference in reproductive competence between cows with persistent $C L$ and normal cyclic cows, another study showed that persistent CLs was followed by a higher level of late embryonic and early foetal mortality (Lamming \& Darwash 1998). In our own study performed recently, we reduced the prevalence of persistent CLs by an exogenous injection of $\mathrm{PGF}_{2 \alpha}$ in cows showing a CL five weeks after parturition (Kögel et al. 2014). This treatment led to a significant increase in first service conception rate, a decrease in the AI per conception ratio and a shortened calving-toconception interval.

It is a widely accepted hypothesis that elevated PGF $_{2 \alpha}$ synthesis induced by inflammatory diseases may be responsible for higher embryonic loss rate in pregnant cows (Hansen et al. 2004). In fact, it has been demonstrated that cows affected by clinical mastitis within the period between first $\mathrm{Al}$ and pregnancy require more inseminations and have a longer calvingto-conception interval compared to healthy cows (Barker et al. 1998). The authors stated that the inflammation-related induction of complete luteolysis was responsible for the termination of pregnancy. However, in further experimental studies a single intravenous administration of LPS between days 7 and 9 of the oestrous cycle in cows caused only a transient decrease of luteal size and P4 concentrations (Fig. 4). Although the cows infused with LPS showed lower $\mathrm{P} 4$ values for some days compared to untreated control cows, the duration of the oestrous cycle was not significantly altered (Gilbert et al. 1990, Herzog et al. 2012).

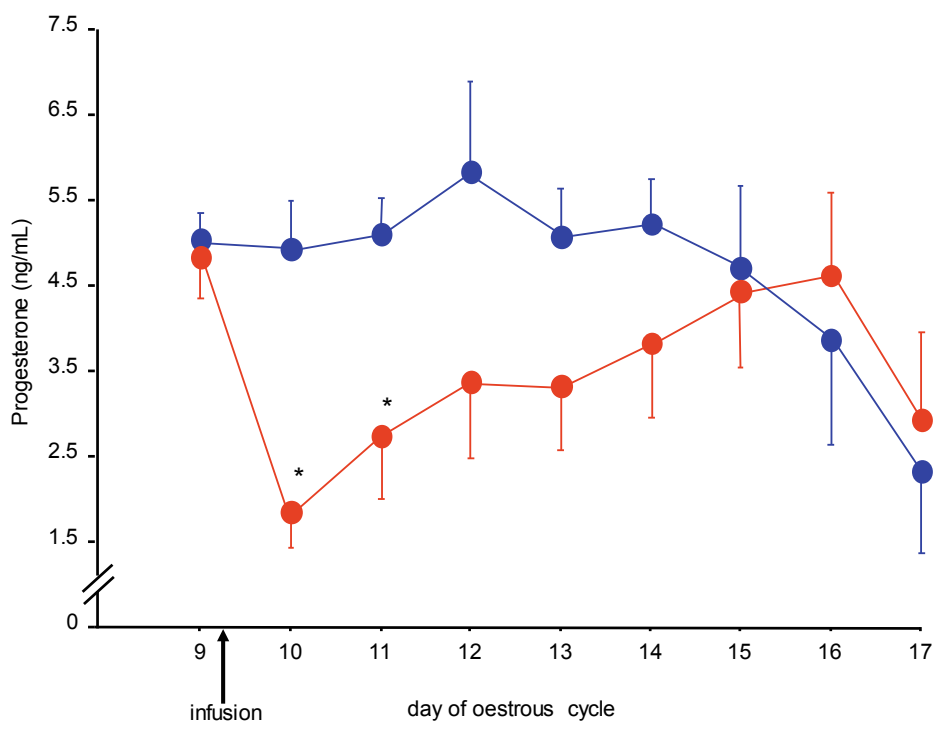

Fig. 4. Plasma progesterone concentration (mean +/-S.E.M.) in cows given saline (blue) or E. coli lipopolysaccharides (red) on day 9 of the oestrous cycle. *Values differed between saline- and LPS-treated cows ( $\mathrm{P} \leq 0.05)$ (mod. from Herzog et al. 2012). 
Furthermore, after an intrauterine infusion of LPS, systemic P4 concentrations were found to be decreased over several days (Williams et al. 2008). In a recently completed trial we infused LPS intravenously in eight pregnant cows between days 29 and 38 after successful insemination. In these cows LPS induced reduced P4 concentrations, but no embryonic loss was observed in any of the cows (Herzog et al. 2014). The results of these studies suggest that a short term exposure to endotoxins provokes a temporary depression in luteal function, but does not necessarily cause further negative consequences. It cannot be excluded, however, that a chronic, long-lasting exposure to either endotoxins or other components of bacteria might induce complete luteolysis leading to embryonic mortality.

\section{Effects on uterine involution}

Uterine involution during the puerperal period is an important and critical process in the reproductive cycle of dairy cows (Frazer 2005). It includes the reduction of uterine size, elimination of bacterial contamination and regeneration of the endometrium representing preconditions for a subsequent pregnancy (Sheldon et al. 2008). During the first three weeks after parturition, the weight of the uterus decreases from $9 \mathrm{~kg}$ to around $1 \mathrm{~kg}$ (Gier \& Marion 1968). Indeed, a variety of hormones play a crucial role in the regulation of uterine contractility (Frazer 2005). The muscle cells of the uterus express high-affinity receptors for oestrogens, P4, oxytocin and prostaglandins as well as adrenaline and norepinephrine (Kundig et al. 1990). Oestrogens have a contraction-promoting effect on the myometrium, while P4 immobilizes the myometrium (Garfield et al. 1988).

Cows suffering from uterine diseases due to disturbances of uterine involution show a calving-to-conception interval approximately 19 days longer and a 20\% lower conception rate to first service compared to controls (Fourichon et al. 2000). Even after clinical resolution of a uterine infection, conception rates remain about $20 \%$ lower in affected cows. Finally, $3 \%$ of such cows remain infertile and have to be culled (Borsberry \& Dobson 1989).

The main issues affecting uterine involution during the puerperium are a retained placenta and uterine infections (Fonseca et al. 1983, Borsberry \& Dobson 1989), mostly associated with peripartal complications such as dystocia, twins or stillbirths. Dystocia is usually associated with human obstetrical assistance resulting in an increased contamination of the uterus and vagina. A retained placenta contributes to the pathogenesis of metritis by providing an ideal environment for bacterial growth, due to the large amount of necrotic tissue present, the delay of lochia expulsion and potential lesions to the uterus because of manual removal. Thus, bacterial uterine inflammation is a common consequence (LeBlanc et al. 2002, Dubuc et al. 2010a, Sheldon \& Dobson 2004). However, it is important to note that during the first days after parturition the uterus is contaminated with a wide range of bacteria in nearly all cows. The development of metritis is dependent on the balance between immunity of the cow and pathogenicity of the bacteria (Sheldon et al. 2009).

There are conflicting results concerning the effects of metabolites and production diseases on uterine involution. LeBlanc (2012) reviewed the interaction between metabolism, inflammation and fertility and concluded that NEB contributes to immune dysfunction, a major factor in the establishment of reproductive tract inflammatory disease. Hammon et al. (2006) noticed that high serum concentrations of ß-hydroxybutyrate (BHBA) and NEFA reduce the activity of polymorphonuclear neutrophils (PMN), which play an important role in uterine immune defence and are involved in the pathophysiology of metritis. This finding is supported by another study showing that cows with uterine diseases had higher serum concentrations of NEFA and BHBA around calving (Galvao et al. 2010). It has also been suggested that cows with pronounced 
NEB reveal an increased expression of inflammatory genes in the endometrium 2 weeks after calving (Wathes et al. 2009). However, other studies did not find an interaction between NEB and uterine disease. Similar concentrations of NEFA and glucose were observed in cows with and without endometritis (Burke et al. 2010), and neither NEFA nor BHBA during early lactation were found to have an association with metritis (Valergakis et al. 2011) or subclinical endometritis (Senosy et al. 2012). Markusfeld (1987) described an increased risk of retained placenta related to the body condition of cows with distinct BCS losses during the dry period. Also cows with a low BCS were more likely to have retained placental membranes. However, in another study no relationship between BCS and the incidence of metritis was observed (Kim \& Kang 2003).

Hypocalcaemia causes a reduced uterine muscle tone, which could be responsible for retained placenta and a delay in uterine involution (Erb et al. 1985). Low blood calcium levels may also be associated with impaired immune function, but their association with uterine diseases is also equivocal. In one case-control study, with a relatively low number of cows $(n=38)$, clinical hypocalcaemia was associated with a higher prevalence of purulent vaginal discharge about three weeks after parturition (Whiteford \& Sheldon 2005). However, in large field studies with several hundred cows, no relationship between the occurrence of hypocalcaemia and uterine diseases was found (Dubuc et al. 2010b, Cheong et al. 2011).

The reasons for these discrepancies have not been clarified and need further investigation. Different factors are intricately interlinked, which makes assessment of these single effects difficult (Williams 2013). Recently it has been shown that different risk factors are associated with different forms of uterine disease. Factors that increase uterine trauma and bacterial contamination, such as twinning and dystocia, are more likely to result in purulent vaginal discharge without an endometrial inflammation. Factors associated with either immune suppression or metabolic disturbances during the transition period, such as a thin body condition at calving or ketosis, result more often in endometritis as diagnosed by cytology (Dubuc et al. 2010b). Perivaginal discharge and cytological endometritis both reduce the probability of a subsequent pregnancy. As the effects are cumulative in cows showing both conditions, the authors of these studies concluded that the effects have a different origin (Dubuc et al. 2010a).

There are contradictory statements on the effects of the time of first ovulation after parturition on reproductive performance in cows. Some studies demonstrated that a short postpartum anovulatory period is associated with improved fertility (Thatcher \& Wilcox 1973, Darwash et al. 1997a, Kawashima et al. 2006, Gautam et al. 2010), whereas others reported reduced fertility (Smith \& Wallace 1998) or did not find any effect (Sakaguchi et al. 2004). Previous experimental studies on the effect of the postpartum anovulatory interval on fertility of dairy cows used either oestrogens or $\mathrm{GnRH}$ analogues for postpartum suppression of ovulation (Haughian et al. 2002, Padula \& Macmillan 2002, Silvestre et al. 2009a, Silvestre et al. 2009b, Silvestre et al. 2009c). However, whether and to what extent uterine effects were caused indirectly by either the suppression of ovulation or directly by the administered hormones, is not known. Oestrogens have a positive effect on myometrial contractility and enhance uterine immune response (Killingbeck \& Lamming 1963, Rodriguez-Martinez et al. 1987, Herath et al. 2007, Silvestre et al. 2009a, Shimizu et al. 2012), whereas P4 induces a relaxation of uterine muscles (Rodriguez-Martinez et al. 1987, Bonafos et al. 1995) and suppresses immunity (Lander Chacin et al. 1990, Subandrio et al. 2000). GnRH analogues also enhance uterine motility (Giammarino et al. 2009). In our own study we inhibited ovulation during puerperium in healthy dairy cows and in cows with postpartum uterine disease without hormonal treatments by repeated transvaginal follicular punctures (Heppelmann et al. 2013). Suppression of ovulation by transvaginal follicular punctures had a positive effect on uterine involution especially in cows 
with uterine disease. This supports the suggestion that postpartum suppression of ovulation, and thus delayed secretion of P4, enhances the reduction in uterine size and the elimination of inflammation and bacterial contamination. These findings advocate against early induction of ovulation in cows with postpartum uterine disease.

\section{Conclusions}

Reduced fertility in dairy cows is not an inevitable consequence of high milk yield. Instead, production diseases, as well as infertility, may be caused by a variety of different factors including the consequence of an insufficient adaptation capacity of the respective cows to cope with the metabolic challenge during the transition period. Both, metabolic disorders and inflammatory processes have multifarious negative impacts on the onset of ovarian activity after parturition, uterine involution and oestrus behavior (Fig. 5). Until now, research has focused mainly on either the effects of NEB or production diseases on reproductive function. In future, more investigations should be performed to understand what happens to the reproductive system in cows experiencing NEB while suffering from a production disease at the same time.

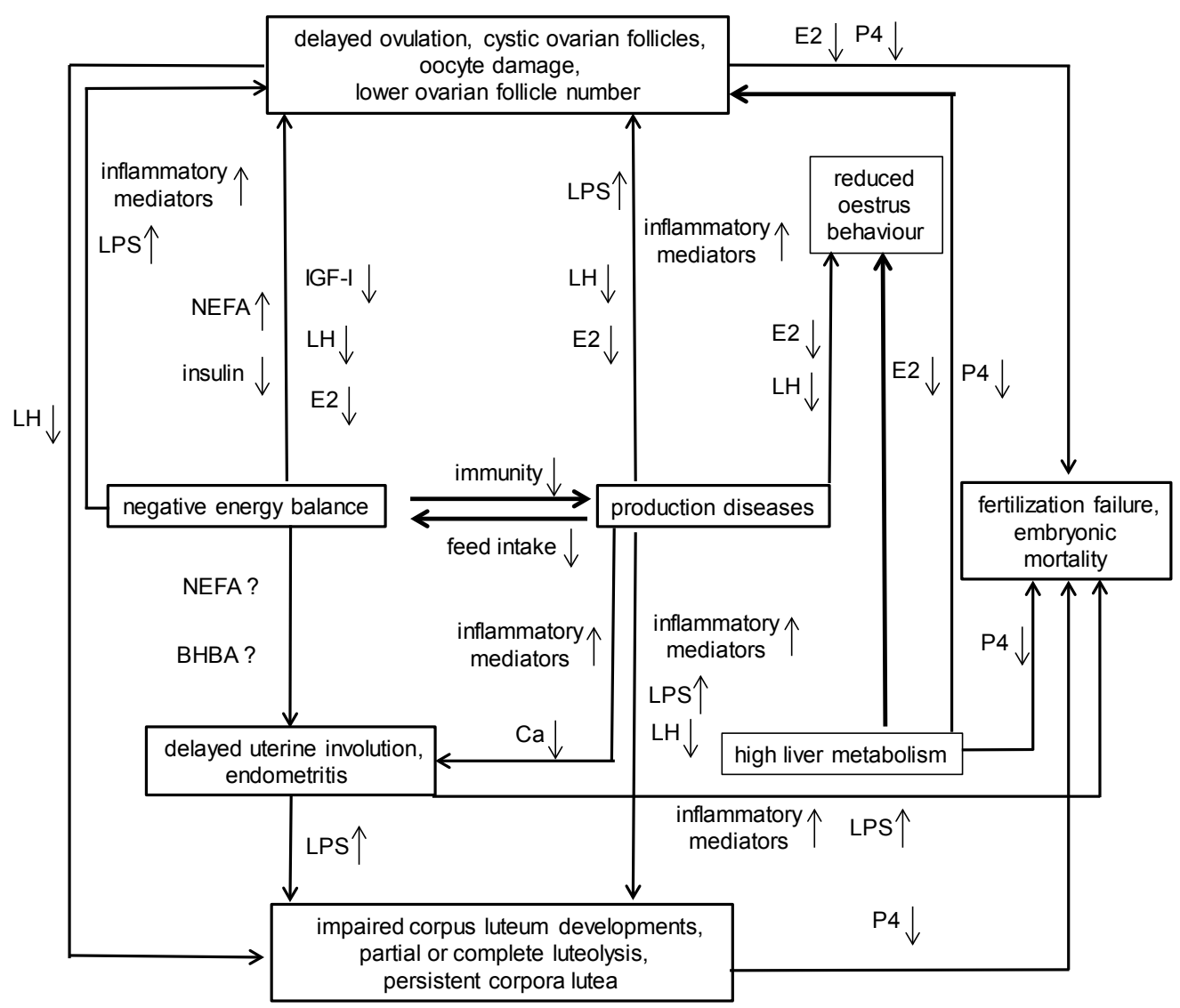

Fig. 5. Schematic outline of the interaction between metabolism and production dieases and their effects on reproductive performance of dairy cows. 
Moreover, there is a lack of knowledge about the influence of robustness in dairy cows. Many high-yielding dairy cows remain healthy and fertile resulting in longevity. The differences and influence of the metabolic constellation contributing to fertility between higher yielding and lower yielding cows need specific attention and further clarification.

\section{References}

Akinlosotu BA, Diehl JR \& Gimenez T 1986 Sparing effects of intrauterine treatment with prostaglandin E2 on luteal function in cycling gilts. Prostaglandins 32 291-299.

Andersen JB, Friggens NC, Larsen T, Vestergaard M \& Ingvartsen KL 2004 Effect of energy density in the diet and milking frequency on plasma metabolites and hormones in early lactation dairy cows. J Vet Med A Physiol Pathol Clin Med 51 52-57.

Armstrong DG, Gong JG \& Webb R 2003 Interactions between nutrition and ovarian activity in cattle: physiological, cellular and molecular mechanisms. Reprod Supp/ 61 403-414.

Armstrong DG, McEvoy TG, Baxter G, Robinson JJ, Hogg CO, Woad KJ, Webb R \& Sinclair KD 2001 Effect of dietary energy and protein on bovine follicular dynamics and embryo production in vitro: associations with the ovarian insulin-like growth factor system. Biol Reprod 64 1624-1632.

Barker AR, Schrick FN, Lewis MJ, Dowlen HH \& Oliver SP 1998 Influence of clinical mastitis during early lactation on reproductive performance of Jersey cows. J Dairy Sci 81 1285-1290.

Bauman DE \& Currie WB 1980 Partitioning of nutrients during pregnancy and lactation: a review of mechanisms involving homeostasis and homeorhesis. J Dairy Sci 63 1514-1529.

Beam SW \& Butler WR 1998 Energy balance, metabolic hormones, and early postpartum follicular development in dairy cows fed prilled lipid. J Dairy Sci 81 121-131.

Bertics SJ, Grummer RR, Cadorniga-Valino C \& Stoddard EE 1992 Effect of prepartum dry matter intake on liver triglyceride concentration and early lactation. J Dairy Sci 75 1914-1922.

Bobe G, Young JW \& Beitz DC 2004 Invited review: pathology, etiology, prevention, and treatment of fatty liver in dairy cows. J Dairy Sci 87 3105-3124.

Bonafos LD, Kot K \& Ginther OJ 1995 Physical characteristics of the uterus during the bovine estrous cycle and early pregnancy. Theriogenology 43 713-721.

Borsberry S \& Dobson H 1989 Periparturient diseases and their effect on reproductive performance in five dairy herds. Vet Rec 124 217-219.

Britt JH 1991 Impacts of early postpartum metabolism on follicular development and fertility. The Bovine Practitioner Proceedings 24, pp. 39-43.

Bromfield JJ \& Sheldon IM 2013 Lipopolysaccharide reduces the primordial follicle pool in the bovine ovarian cortex ex vivo and in the murine ovary in vivo. Biol Reprod $\mathbf{8 8} 98$.

Burke CR, Meier S, McDougall S, Compton C, Mitchell M \& Roche JR 2010 Relationships between endometritis and metabolic state during the transition period in pasture- grazed dairy cows. J Dairy Sci 93 5363-5373.

Carter F, Forde N, Duffy P, Wade M, Fair T, Crowe MA, Evans AC, Kenny DA, Roche JF \& Lonergan P 2008 Effect of increasing progesterone concentration from Day 3 of pregnancy on subsequent embryo survival and development in beef heifers. Reprod Fertil Dev 20 368-375.

Castro N1, Kawashima C, van Dorland HA, Morel I, Miyamoto A \& Bruckmaier RM 2012 Metabolic and energy status during the dry period is crucial for the resumption of ovarian activity postpartum in dairy cows. J Dairy Sci 95 5804-5812.

Cerri RL, Santos JE, Juchem SO, Galvao KN \& Chebel RC 2004 Timed artificial insemination with estradiol cypionate or insemination at estrus in high-producing dairy cows. J Dairy Sci 87 3704-3715.

Cheong SH, Nydam DV, Galvao KN, Crosier BM \& Gilbert RO 2011 Cow-level and herd-level risk factors for subclinical endometritis in lactating Holstein cows. J Dairy Sci 94 762-770.

Chilliard Y, Bocquier F \& Doreau M 1998 Digestive and metabolic adaptations of ruminants to undernutrition, and consequences on reproduction. Reprod Nutr Dev 38 131-152.

Davis ME \& Simmen RC 1997 Genetic parameter estimates for serum insulin-like growth factor I concentration and performance traits in Angus beef cattle. J Anim Sci 75 317-24.

Davis ME \& Simmen RC 2006 Genetic parameter estimates for serum insulin-like growth factor I concentrations, and body weight and weight gains in Angus beef cattle divergently selected for serum insulin-like growth factor I concentration. J Anim Sci 84 2299-2308.

Darwash AO, Lamming GE \& Woolliams JA 1997a Estimation of genetic variation in the interval from calving to postpartum ovulation of dairy cows. J Dairy Sci $\mathbf{8 0}$ 1227-1234.

Darwash AO, Lamming GE \& Woolliams JA 1997b The phenotypic association between the interval to postpartum ovulation and traditional measures of fertility in dairy cattle. Anim Sci 65 9-16.

Del Vecchio RP, Matsas DJ, Fortin S, Sponenberg DP \& Lewis GS 1994 Spontaneous uterine infections are associated with elevated prostaglandin F(2)alpha metabolite concentrations in postpartum dairy cows. Theriogenology 41 413-421.

De Koster JD \& Opsomer G. 2013 Insulin resistance in dairy cows. Vet Clin North Am Food Anim Pract. 29 299-322.

Diskin MG \& Morris DG 2008 Embryonic and early foetal losses in cattle and other ruminants. Reprod Domest Anim 43 Suppl 2 260-267. 
Dobson H, Smith R, Royal M, Knight C \& Sheldon I 2007 The high-producing dairy cow and its reproductive performance. Reprod Domest Anim 42 Suppl 2 17-23.

Dobson H \& Smith RF 2000 What is stress, and how does it affect reproduction? Anim Reprod Sci 60-61 743-752.

Dobson H, Walker SL, Morris MJ, Routly JE \& Smith RF 2008 Why is it getting more difficult to successfully artificially inseminate dairy cows? Animal 2 1104-1111.

Dominici FP \& Turyn D 2002 Growth hormone-induced alterations in the insulin-signaling system. Exp Biol Med (Maywood) 227 149-157.

Dubuc J, Duffield TF, Leslie KE, Walton JS \& LeBlanc S) 2010a Definitions and diagnosis of postpartum endometritis in dairy cows. J Dairy Sci 93 5225-5233.

Dubuc J, Duffield TF, Leslie KE, Walton JS \& LeBlanc SJ 2010 b Risk factors for postpartum uterine diseases in dairy cows. J Dairy Sci 93 5764-5771.

Duffield TF, Rabiee AR \& Lean IJ 2008 A meta-analysis of the impact of monensin in lactating dairy cattle. Part 1. Metabolic effects. J Dairy Sci 91 1334-1346.

Erb HN, Smith RD, Oltenacu PA, Guard CL, Hillman RB, Powers PA, Smith MC \& White ME 1985 Path model of reproductive disorders and performance, milk fever, mastitis, milk yield, and culling in Holstein cows. J Dairy Sci 68 3337-3349.

Evans AC, Mossa F, Walsh SW, Scheetz D, Jimenez-Krassel F, Ireland JL, Smith GW \& Ireland JJ 2012 Effects of maternal environment during gestation on ovarian folliculogenesis and consequences for fertility in bovine offspring. Reprod Domest Anim 47 Suppl 4 31-37.

Fleischer P, Metzner M, Beyerbach M, Hoedemaker M \& Klee W 2001 The relationship between milk yield and the incidence of some diseases in dairy cows. J Dairy Sci 84 2025-2035.

Fonseca FA, Britt JH, McDaniel BT, Wilk JC \& Rakes AH 1983 Reproductive traits of Holsteins and Jerseys. Effects of age, milk yield, and clinical abnormalities on involution of cervix and uterus, ovulation, estrous cycles, detection of estrus, conception rate, and days open. J Dairy Sci $\mathbf{6 6}$ 1128-1147.

Fourichon C, Seegers H \& Malher X 2000 Effect of disease on reproduction in the dairy cow: a meta-analysis. Theriogenology 53 1729-1759.

Frazer GS 2005 A rational basis for therapy in the sick postpartum cow. Vet Clin North Am Food Anim Pract 21 523-568.

Galvao KN, Flaminio MJ, Brittin SB, Sper R, Fraga M, Caixeta L, Ricci A, Guard CL, Butler WR \& Gilbert RO 2010 Association between uterine disease and indicators of neutrophil and systemic energy status in lactating Holstein cows. J Dairy Sci 93 2926-2937.

Galvao KN, Santos JE, Juchem SO, Cerri RL, Coscioni AC \& Villasenor M 2004 Effect of addition of a progesterone intravaginal insert to a timed insemination protocol using estradiol cypionate on ovulation rate, pregnancy rate, and late embryonic loss in lactating dairy cows. J Anim Sci 82 3508-3517.

Garfield RE, Blennerhassett MG \& Miller SM 1988 Control of myometrial contractility: role and regulation of gap junctions. Oxf Rev Reprod Biol 10 436-490.
Gautam G, Nakao T, Yamada K \& Yoshida C 2010 Defining delayed resumption of ovarian activity postpartum and its impact on subsequent reproductive performance in Holstein cows. Theriogenology 73 180-189.

Giammarino A, Manera M, Robbe D, Perugini M \& Amorena M 2009 The effect of GnRH on in vitro bovine myometrial activity. Anim Reprod Sci 112 325-333.

Gier HT \& Marion GB 1968 Uterus of the cow after parturition: involutional changes. Am J Vet Res 29 83-96.

Gilbert RO, Bosu WT \& Peter AT 1990 The effect of Escherichia coli endotoxin on luteal function in Holstein heifers. Theriogenology 33 645-651.

Gimenez T \& Henricks DM 1983 Prolongation of the luteal phase by prostaglandin $\mathrm{E}(2)$ during the estrous cycle in the cow. A preliminary report. Theriogenology 19 693-700.

Giuliodori MJ, Delavaud C, Chilliard Y, Becú-Villalobos D, Lacau-Mengido I \& De la Sota RL 2011 High NEFA concentrations around parturition are associated with delayed ovulations in grazing dairy cows. Livestock Sci 141 123-128.

Gong JG 2002 Influence of metabolic hormones and nutrition on ovarian follicle development in cattle: practical implications. Domest Anim Endocrinol 23 229-241.

Grochowska R, Sørensen P, Zwierzchowski L, Snochowski M \&Løvendahl P 2001 Genetic variation in stimulated $\mathrm{GH}$ release and in IGF-1 of young dairy cattle and their associations with the leucine/valine polymorphism in the GH gene. J Anim Sci 79 470-476.

Gumen A, Guenther JN \& Wiltbank MC 2003 Follicular size and response to Ovsynch versus detection of estrus in anovular and ovular lactating dairy cows. J Dairy Sci 86 3184-3194.

Gumen A, Rastani RR, Grummer RR \& Wiltbank MC 2005 Reduced dry periods and varying prepartum diets alter postpartum ovulation and reproductive measures. J Dairy Sci 88 2401-2411.

Hakogi E, Tamura H, Tanaka S, Kohata A, Shimada Y \& Tabuchi K 1989 Endotoxin levels in milk and plasma of mastitis-affected cows measured with a chromogenic limulus test. Vet Microbiol 20 267-274.

Hammon DS, Evjen IM, Dhiman TR, Goff JP \& Walters JL 2006 Neutrophil function and energy status in Holstein cows with uterine health disorders. Vet Immunol Immunopathol 113 21-29.

Hansen PJ, Soto P \& Natzke RP 2004 Mastitis and fertility in cattle-possible involvement of inflammation or immune activation in embryonic mortality. Am J Reprod Immunol 51 294-301.

Harrison RO, Ford SP, Young JW, Conley AJ \& Freeman AE 1990 Increased milk production versus reproductive and energy status of high producing dairy cows. J Dairy Sci 73 2749-2758.

Haughian JM, Sartori R, Guenther JN, Gumen A \& Wiltbank MC 2002 Extending the postpartum anovulatory period in dairy cattle with estradiol cypionate. J Dairy Sci 85 3238-3249.

Hayirli A, Bertics SJ \& Grummer RR 2002 Effects of slowrelease insulin on production, liver triglyceride, and metabolic profiles of Holsteins in early lactation. J Dairy Sci 85 2180-2191. 
Henderson KM, Scaramuzzi RJ \& Baird DT 1977 Simultaneous infusion of prostaglandin E2 antagonizes the luteolytic action of prostaglandin F2alpha in vivo. J Endocrinol 72 379-383.

Heppelmann M, Brommling A, Weinert M, Piechotta M, Wrenzycki C \& Bollwein H 2013 Effect of postpartum suppression of ovulation on uterine involution in dairy cows. Theriogenology 80 519-525.

Herath S, Williams EJ, Lilly ST, Gilbert RO, Dobson H, Bryant CE \& Sheldon IM 2007 Ovarian follicular cells have innate immune capabilities that modulate their endocrine function. Reproduction 134 683-693.

Herdt TH 1988 Fuel homeostasis in the ruminant. Vet Clin North Am Food Anim Pract 4 213-231.

Herdt TH 2000 Ruminant adaptation to negative energy balance. Influences on the etiology of ketosis and fatty liver. Vet Clin North Am Food Anim Pract 16 215-230, v.

Hernandez JA, Risco CA, Lima FS \& Santos JE (2012) Observed and expected combined effects of clinical mastitis and low body condition on pregnancy loss in dairy cows. Theriogenology 77 115-121.

Herzog K, Debertolis L, Piechotta M, Ulbrich SE \& Bollwein H 2014. Intravenous administration of lipopolysaccharides suppresses luteal function transiently but does not cause late embryonic mortality in pregnant cows. p. 24: Reprod Domest Anim.

Herzog K, Struve K, Kastelic JP, Piechotta M, Ulbrich SE, Pfarrer C, Shirasuna K, Shimizu T, Miyamoto A \& Bollwein H 2012 Escherichia coli lipopolysaccharide administration transiently suppresses luteal structure and function in diestrous cows. Reproduction 144 467-476.

Holtenius K, Agenas S, Delavaud C \& Chilliard Y 2003 Effects of feeding intensity during the dry period. 2. Metabolic and hormonal responses. J Dairy Sci 86 883-891.

Ingvartsen KL \& Andersen JB 2000 Integration of metabolism and intake regulation: a review focusing on periparturient animals. J Dairy Sci 83 1573-1597.

Inskeep EK 2004 Preovulatory, postovulatory, and postmaternal recognition effects of concentrations of progesterone on embryonic survival in the cow. I Anim Sci 82 E-Suppl E24-39.

Ireland JJ, Smith GW, Scheetz D, Jimenez-Krassel F, Folger JK, Ireland JL, Mossa F, Lonergan P \& Evans AC 2011 Does size matter in females? An overview of the impact of the high variation in the ovarian reserve on ovarian function and fertility, utility of anti-Mullerian hormone as a diagnostic marker for fertility and causes of variation in the ovarian reserve in cattle. Reprod Fertil Dev 23 1-14.

Kaske M, Kräft S, Herzog K \& Rehage J 2004. Pancreatic insulin response and tissue responsiveness to insulin in dry cows, lactating cows and cows suffering from fatty liver and ketosis. Proc. 22nd Am Coll Vet Intern Med pp. 239-240.

Kawashima C, Fukihara S, Maeda M, Kaneko E, Montoya CA, Matsui M, Shimizu T, Matsunaga N, Kida K, Miyake Y, Schams D \& Miyamoto A 2007a Relationship between metabolic hormones and ovulation of dominant follicle during the first follicular wave post-partum in highproducing dairy cows. Reproduction 133 155-163.

Kawashima C, Kaneko E, Amaya Montoya C, Matsui M, Yamagishi N, Matsunaga N, Ishii M, Kida K, Miyake
Y \& Miyamoto A 2006 Relationship between the first ovulation within three weeks postpartum and subsequent ovarian cycles and fertility in high producing dairy cows. J Reprod Dev 52 479-486.

Kawashima C, Matsui M, Shimizu T, Kida K \& Miyamoto A 2012 Nutritional factors that regulate ovulation of the dominant follicle during the first follicular wave postpartum in high-producing dairy cows. J Reprod Dev 58 10-16.

Kawashima C, Sakaguchi M, Suzuki T, Sasamoto Y, Takahashi Y, Matsui M \& Miyamoto A 2007b Metabolic profiles in ovulatory and anovulatory primiparous dairy cows during the first follicular wave postpartum. J Reprod Dev 53 113-120.

Killingbeck J \& Lamming GE 1963 Influence of uterine secretions on phagocytosis. Nature 198 111-112.

Kinder JE, Kojima FN, Bergfeld EG, Wehrman ME \& Fike KE 1996 Progestin and estrogen regulation of pulsatile LH release and development of persistent ovarian follicles in cattle. J Anim Sci 74 1424-1440.

Kögel T, Lüttgenau J \& Bollwein H 2014. Does an early induced ovulation or luteolysis reduce the incidence of ovarian cysts and persisting corpora lutea in postpartum dairy cows?, p. 28: Reprod Domest Anim.

Konigsson K, Savoini G, Govoni N, Invernizzi G, Prandi A, Kindahl H \& Veronesi MC 2008 Energy balance, leptin, NEFA and IGF-I plasma concentrations and resumption of post partum ovarian activity in Swedish Red and White breed cows. Acta Vet Scand $\mathbf{5 0} 3$.

Kundig H, Thun R, Zerobin K \& Bachmann B 1990 [The uterine motility of cattle during late pregnancy, labor and puerperium. I. Spontaneous motility]. Schweiz Arch Tierheilkd 132 77-84.

Kunz PL, Blum JW, Hart IC, Bickel H \& Landis J 1985 Effects of different energy intakes before and after calving on food intake, performance and blood hormones and metabolites in dairy cows. Anim Prod 40 219-231.

La Marca A \& Volpe A 2006 Anti-Mu“llerian hormone $(\mathrm{AMH})$ in female reproduction: is measurement of circulating $\mathrm{AMH}$ a useful tool? Clin Endocrinol 64 603-610.

Lamming GE \& Darwash AO 1998 The use of milk progesterone profiles to characterise components of subfertility in milked dairy cows. Anim Reprod Sci 52 175-190.

Lander Chacin MF, Hansen PJ \& Drost M 1990 Effects of stage of the estrous cycle and steroid treatment on uterine immunoglobulin content and polymorphonuclear leukocytes in cattle. Theriogenology 34 1169-1184.

Lang CH \& Frost RA 2002 Role of growth hormone, insulinlike growth factor-I, and insulin-like growth factor binding proteins in the catabolic response to injury and infection. Curr Opin Clin Nutr Metab Care 5 271-279.

LeBlanc SJ 2012 Interactions of metabolism, inflammation, and reproductive tract health in the postpartum period in dairy cattle. Reprod Domest Anim 47 Suppl 5 18-30.

LeBlanc SJ, Duffield TF, Leslie KE, Bateman KG, Keefe GP, Walton JS \& Johnson WH 2002 Defining and diagnosing postpartum clinical endometritis and its impact on reproductive performance in dairy cows. J Dairy Sci $\mathbf{8 5}$ 2223-2236. 
Leroy JL, Vanholder T, Opsomer G, Van Soom A \& de Kruif A 2006 The in vitro development of bovine oocytes after maturation in glucose and beta-hydroxybutyrate concentrations associated with negative energy balance in dairy cows. Reprod Domest Anim 41 119-123.

Lonergan P 2011 Influence of progesterone on oocyte quality and embryo development in cows. Theriogenology $\mathbf{7 6}$ 1594-1601.

Lopez H, Satter LD \& Wiltbank MC 2004 Relationship between level of milk production and estrous behavior of lactating dairy cows. Anim Reprod Sci 81 209-223.

Lucy MC 2000 Regulation of ovarian follicular growth by somatotropin and insulin-like growth factors in cattle. J Dairy Sci 83 1635-1647.

Lucy MC, Staples CR, Thatcher WW, Erickson PS, Cleale RM, Firkins JL, Clark JH, Murphy MR \& Brodie BO 1992 Influence of diet composition, dry matter intake, milk production and fertility in dairy cows. Anim Prod 54 323-331.

Mann GE \& Lamming GE 2000 The role of sub-optimal preovulatory oestradiol secretion in the aetiology of premature luteolysis during the short oestrous cycle in the cow. Anim Reprod Sci 64 171-180.

Markusfeld O 1987 Periparturient traits in seven high dairy herds. Incidence rates, association with parity, and interrelationships among traits. J Dairy Sci 70 158-166.

Mateus L, da Costa LL, Bernardo F \& Silva JR 2002 Influence of puerperal uterine infection on uterine involution and postpartum ovarian activity in dairy cows. Reprod Domest Anim 37 31-35.

Mateus L, da Costa LL, Diniz P \& Ziecik AJ 2003 Relationship between endotoxin and prostaglandin (PGE2 and PGFM) concentrations and ovarian function in dairy cows with puerperal endometritis. Anim Reprod Sci 76 143-154.

Meikle A, Kulcsar M, Chilliard Y, Febel H, Delavaud C, Cavestany D \& Chilibroste P 2004 Effects of parity and body condition at parturition on endocrine and reproductive parameters of the cow. Reproduction 127 727-737.

Mihm M, Baguisi A, Boland MP \& Roche JF 1994 Association between the duration of dominance of the ovulatory follicle and pregnancy rate in beef heifers. J Reprod Fertil 102 123-130.

Mihm M, Curran N, Hyttel P, Knight PG, Boland MP \& Roche JF 1999 Effect of dominant follicle persistence on follicular fluid oestradiol and inhibin and on oocyte maturation in heifers. J Reprod Fertil 116 293-304.

Mossa F, Carter F, Walsh SW, Kenny DA, Smith GW, Ireland JL, Hildebrandt TB, Lonergan P, Ireland JJ \& Evans AC 2013 Maternal undernutrition in cows impairs ovarian and cardiovascular systems in their offspring. Biol Reprod 8892.

Mossa F, Walsh SW, Butler ST, Berry DP, Carter F, Lonergan P, Smith GW, Ireland J] \& Evans AC 2012 Low numbers of ovarian follicles $>/=3 \mathrm{~mm}$ in diameter are associated with low fertility in dairy cows. J Dairy Sci 95 2355-2361.

Mulligan FJ \& Doherty ML 2008 Production diseases of the transition cow. Vet / 176 3-9.

Opsomer G, Grohn YT, Hertl J, Coryn M, Deluyker H \& de Kruif A 2000 Risk factors for post partum ovarian dysfunction in high producing dairy cows in Belgium: a field study. Theriogenology 53 841-857.

Padula AM \& Macmillan KL 2002 Reproductive responses of early postpartum dairy cattle to continuous treatment with a GnRH agonist (deslorelin) for 28 days to delay the resumption of ovulation. Anim Reprod Sci 70 23-36.

Petroff MG, Petroff BK \& Pate JL 2001 Mechanisms of cytokine-induced death of cultured bovine luteal cells. Reproduction 121 753-760.

PiechottaM, Sander AK, Kastelic JP, Wilde R, Heppelmann M, Rudolphi B, Schuberth HJ, Bollwein H \& Kaske M 2012 Short communication: Prepartum plasma insulinlike growth factor-I concentrations based on day of insemination are lower in cows developing postpartum diseases. J Dairy Sci 95 1367-1370.

Pitkala A, Haveri M, Pyorala S, Myllys V \& Honkanen-Buzalski T 2004 Bovine mastitis in Finland 2001-Prevalence, distribution of bacteria, and antimicrobial resistance. J Dairy Sci 87 2433-2441.

Pollott GE \& Coffey MP 2008 The effect of genetic merit and production system on dairy cow fertility, measured using progesterone profiles and on-farm recording. J Dairy Sci 91 3649-3660.

Reynolds LP, Robertson DA \& Ford SP 1983 Effects of intrauterine infusion of oestradiol-17 beta and prostaglandin E-2 on luteal function in non-pregnant heifers. J Reprod Fertil 69 703-709.

Rhodes FM, McDougall S, Burke CR, Verkerk GA \& Macmillan KL 2003 Invited review: Treatment of cows with an extended postpartum anestrous interval. J Dairy Sci 86 1876-1894.

Roberts T, Chapinal N, Leblanc SJ, Kelton DF, Dubuc J \& Duffield TF 2012 Metabolic parameters in transition cows as indicators for early-lactation culling risk. J Dairy Sci 95 3057-3063.

Robinson RS, Hammond AJ, Nicklin LT, Schams D, Mann GE \& Hunter MG 2006 Endocrine and cellular characteristics of corpora lutea from cows with a delayed post-ovulatory progesterone rise. Domest Anim Endocrinol 31 154-172.

Rodriguez-Martinez H, McKenna D, Weston PG, Whitmore HL \& Gustafsson BK 1987 Uterine motility in the cow during the estrous cycle. I. Spontaneous activity. Theriogenology 27 337-348.

Sakaguchi M, Sasamoto Y, Suzuki T, Takahashi Y \& Yamada Y 2004 Postpartum ovarian follicular dynamics and estrous activity in lactating dairy cows. J Dairy Sci $\mathbf{8 7}$ 2114-2121.

Sangsritavong S, Combs DK, Sartori R, Armentano LE \& Wiltbank MC 2002 High feed intake increases liver blood flow and metabolism of progesterone and estradiol17beta in dairy cattle. J Dairy Sci 85 2831-2842.

Savio JD, Boland MP, Hynes N \& Roche JF 1990a Resumption of follicular activity in the early post-partum period of dairy cows. J Reprod Fertil 88 569-579.

Savio, JD, Boland MP \& Roche JF 1990b Development of dominant follicles and length of ovarian cycles in postpartum dairy cows. J Reprod Fertil 88 581-591.

Schlamberger G, Wiedemann S, Viturro E, Meyer HH \& Kaske M 2010 Effects of continuous milking during the dry period or once daily milking in the first 4 weeks of lactation on metabolism and productivity of dairy cows. J Dairy Sci 93 2471-2485. 
Senosy WS, Izaike Y \& Osawa T 2012 Influences of metabolic traits on subclinical endometritis at different intervals postpartum in high milking cows. Reprod Domest Anim 47 666-674.

Shaham-Albalancy A, Folman Y, Kaim M, Rosenberg M \& Wolfenson D 2001 Delayed effect of low progesterone concentrations on bovine uterine PGF(2alpha) secretion in the subsequent oestrous cycle. Reproduction 122 643-648.

Sheldon IM, Cronin J, Goetze L, Donofrio G \& Schuberth HJ 2009 Defining postpartum uterine disease and the mechanisms of infection and immunity in the female reproductive tract in cattle. Biol Reprod 81,1025-1032.

Sheldon IM \& Dobson H 2004 Postpartum uterine health in cattle. Anim Reprod Sci 82-83 295-306.

Sheldon IM, Williams EJ, Miller AN, Nash DM \& Herath S 2008 Uterine diseases in cattle after parturition. Vet J 176 115-121.

Shimizu T, Miyauchi K, Shirasuna K, Bollwein H, Magata F, Murayama C \& Miyamoto A 2012 Effects of lipopolysaccharide (LPS) and peptidoglycan (PGN) on estradiol production in bovine granulosa cells from small and large follicles. Toxicol In Vitro 26 1134-1142.

Shimizu T, Murayama C, Sudo N, Kawashima C, Tetsuka M \& Miyamoto A 2008 Involvement of insulin and growth hormone $(\mathrm{GH})$ during follicular development in the bovine ovary. Anim Reprod Sci 106 143-152.

Silvestre FT, Bartolome JA, Kamimura S, Arteche AC, Pancarci SM, Trigg T \& Thatcher WW 2009a Postpartum suppression of ovarian activity with a Deslorelin implant enhanced uterine involution in lactating dairy cows. Anim Reprod Sci 110 79-95.

Silvestre FT, Kamimura S, Arteche AC, Bartolome J, Pancarci SM \& Thatcher WW 2009b Reproductive responses following postpartum suppression of ovarian follicular development with a deslorelin implant during summer heat stress in lactating dairy cows. Anim Reprod Sci 111 320-337.

Silvestre FT, Risco CA, Lopez M, de Sa MJ, Bilby TR \& Thatcher WW 2009c Use of increasing doses of a degradable Deslorelin implant to enhance uterine involution in postpartum lactating dairy cows. Anim Reprod Sci 116 196-212.

Swali A \& Wathes DC 2006 Influence of the dam and sire on size at birth and subsequent growth, milk production and fertility in dairy heifers. Theriogenology 66 1173-1184.

Smith MC \& Wallace JM 1998 Influence of early post partum ovulation on the re-establishment of pregnancy in multiparous and primiparous dairy cattle. Reprod Fertil Dev 10 207-216.

Spicer LJ, Alpizar E \& Vernon RK 1994 Insulin-like growth factor-I receptors in ovarian granulosa cells: effect of follicle size and hormones. Mol Cell Endocrinol 102 69-76.

Staples CR, Thatcher WW \& Clark JH 1990 Relationship between ovarian activity and energy status during the early postpartum period of high producing dairy cows. J Dairy Sci 73 938-947.

Ster C, Loiselle MC \& Lacasse P 2012 Effect of postcalving serum nonesterified fatty acids concentration on the functionality of bovine immune cells. J Dairy Sci 95 708-717.

Stronge AJ, Sreenan JM, Diskin MG, Mee JF, Kenny DA \& Morris DG 2005 Post-insemination milk progesterone concentration and embryo survival in dairy cows. Theriogenology 64 1212-1224.

Struve K, Herzog K, Magata F, Piechotta M, Shirasuna K, Miyamoto A \& Bollwein H 2013 The effect of metritis on luteal function in dairy cows. BMC Vet Res 9244.

Subandrio AL, Sheldon IM \& Noakes DE 2000 Peripheral and intrauterine neutrophil function in the cow: the influence of endogenous and exogenous sex steroid hormones. Theriogenology 53 1591-1608.

Sudo N, Shimizu T, Kawashima C, Kaneko E, Tetsuka M \& Miyamoto A 2007 Insulin-like growth factor-I (IGF-I) system during follicle development in the bovine ovary: relationship among IGF-I, type 1 IGF receptor (IGFR-1) and pregnancy-associated plasma protein-A (PAPP-A). Mol Cell Endocrinol 264 197-203.

Suzuki C, Yoshioka K, Iwamura S \& Hirose H 2001 Endotoxin induces delayed ovulation following endocrine aberration during the proestrous phase in Holstein heifers. Domest Anim Endocrinol 20 267-278.

Taylor VJ, Beever DE, Bryant MJ \& Wathes DC 2003 Metabolic profiles and progesterone cycles in first lactation dairy cows. Theriogenology 59 1661-1677.

TaylorVJ, Cheng Z, Pushpakumara PG, Beever DE \& Wathes DC 2004 Relationships between the plasma concentrations of insulin-like growth factor-I in dairy cows and their fertility and milk yield. Vet Rec 155 583-588.

Thatcher WW \& Wilcox CJ 1973 Postpartum estrus as an indicator of reproductive status in the dairy cow. J Dairy Sci 56 608-610.

Thibodeaux JK, Myers MW, Roussel JD \& Godke RA 1992 Intrauterine infusion of prostaglandin E2 and subsequent luteal function in cattle. Prostaglandins 44 531-541.

Thissen JP, Ketelslegers JM \& Underwood LE 1994 Nutritional regulation of the insulin-like growth factors. Endocr Rev 15 80-101.

Thompson FN, Page RD, Cook CB \& Caudle AB 1987 Prostaglandin F2 alpha metabolite levels in normal and uterine-infected postpartum cows. Vet Res Commun 11 503-507.

Valergakis GE, Oikonomou G, Arsenos G \& Banos G 2011 Phenotypic association between energy balance indicators and reproductive performance in primiparous Holstein cows. Vet Rec 168189.

Van Hoeck V, Leroy JL, Arias Alvarez M, Rizos D, GutierrezAdan A, Schnorbusch K, Bols PE, Leese HJ \& Sturmey RG 2013 Oocyte developmental failure in response to elevated nonesterified fatty acid concentrations: mechanistic insights. Reproduction 145 33-44.

Vasconcelos JL, Sartori R, Oliveira HN, Guenther JG \& Wiltbank MC 2001 Reduction in size of the ovulatory follicle reduces subsequent luteal size and pregnancy rate. Theriogenology 56 307-314.

Vazquez-Anon M, Bertics S, Luck M, Grummer RR \& Pinheiro J 1994 Peripartum liver triglyceride and plasma metabolites in dairy cows. J Dairy Sci 77 1521-1528.

Wathes DC, Cheng Z, Chowdhury W, Fenwick MA, 
Fitzpatrick R, Morris DG, Patton J \& Murphy JJ 2009

Negative energy balance alters global gene expression and immune responses in the uterus of postpartum dairy cows. Physiol Genomics 39 1-13.

Whiteford LC \& Sheldon IM 2005 Association between clinical hypocalcaemia and postpartum endometritis. Vet Rec 157 202-203.

Williams CY, Harris TG, Battaglia DF, Viguie C \& Karsch FJ 2001 Endotoxin inhibits pituitary responsiveness to gonadotropin-releasing hormone. Endocrinology 142 1915-1922.

Williams EJ 2013 Drivers of post-partum uterine disease in dairy cattle. Reprod Domest Anim 48 Suppl 1 53-58.

Williams EJ, Fischer DP, Noakes DE, England GC, Rycroft A, Dobson H \& Sheldon IM 2007 The relationship between uterine pathogen growth density and ovarian function in the postpartum dairy cow. Theriogenology 68 549-559.

Williams EJ, Herath S, England GC, Dobson H, Bryant CE \& Sheldon IM 2008 Effect of Escherichia coli infection of the bovine uterus from the whole animal to the cell. Animal 2 1153-1157.

Wilson DJ, Gonzales RN \& Das HH 1997 Bovine mastitis pathogens in New York and Pennsylvania: Prevalence and effects on somatic cell count and milk production. J Dairy Sci 80 2592-2598.

Wiltbank M, Lopez H, Sartori R, Sangsritavong S \& Gumen A 2006 Changes in reproductive physiology of lactating dairy cows due to elevated steroid metabolism. Theriogenology 65 17-29.

Zulu VC, Sawamukai Y, Nakada K, Kida K \& Moriyoshi M 2002 Relationship among insulin-like growth factor-I, blood metabolites and postpartum ovarian function in dairy cows. J Vet Med Sci 64 879-885. 
